\title{
TVET Teacher Professional Competency Framework in Industry 4.0 Era
}

\author{
Dayangku Suraya Awang Jafar ${ }^{1,2, *}$, Muhammad Sukri Saud ${ }^{1}$, Mohd Zolkifli Abd Hamid ${ }^{1}$, \\ Nornazira Suhairom ${ }^{1}$, Mohd Hizwan Mohd Hisham ${ }^{1}$, Yasmin Hanafi Zaid ${ }^{3}$ \\ ${ }^{1}$ Faculty of Social Sciences and Humanities, School of Education, Universiti Teknologi Malaysia (UTM), Malaysia \\ ${ }^{2}$ Institut Latihan Perindustrian Pasir Gudang, Johor, Malaysia \\ ${ }^{3}$ Language Academy, Faculty of Social Sciences and Humanities, Universiti Teknologi Malaysia (UTM), Malaysia
}

Received February 21, 2020; Revised March 26, 2020; Accepted April 19, 2020

Copyright $\subseteq 2020$ by authors, all rights reserved. Authors agree that this article remains permanently open access under the terms of the Creative Commons Attribution License 4.0 International License

\begin{abstract}
Industrial revolution 4.0, which also known as the digital age, is a globalisation era without boundaries. Technological advancement modernises different factors in life and affects many areas, including vocational education. The application of technology in the vocational educational process signifies a shift in the conventional learning paradigm towards more technology-based learning. Therefore, TVET teachers should enhance their competencies to present vocational training that can facilitate future human capital and adapt to new technologies and global challenges in this digital era. A systematic literature review was conducted to investigate TVET Teacher Professional Competency for industry 4.0. Though previous research studies focused on different sets of competencies needed by teachers in industry 4.0, most of them share similar themes. A list of constructs was identified through document analysis. These professional competencies constructs includes technical, non-technical, personal, mental, and physical attributes, as well as motive and self-concept. Each construct was then divided into several related sub-constructs. These findings are then proposed as a framework for developing TVET teacher professional competence in Industry 4.0 era. This study also pointed out that non-technical competency is as important as technical competence and strengthens with teacher personal attributes, their motive, and physical state in the TVET teacher profession. Hence, TVET institutions must open lines for technology adaptability, lifelong learning, and a future set of competencies to meet the challenge of the rapid change in professional competencies requirements for TVET teachers in this digital era.
\end{abstract}

Keywords Teacher Competency, Industry 4.0, Vocational Education, Professional Competencies

\section{Introduction}

Industrial revolution 4.0 is a globalisation era without boundaries [1]. This era is also known as the digital age with a cyber-physical system, augmented reality, simulation, cloud computing, internet of thing, big data, system integration, autonomous operation, and Additive Manufacturing as its pillar [2]. When technology escalates, it raises the global competition [3] and modernises different factors in life, such as cultural, economic, and social, and can fundamentally change our lives and relate to one another $[4,5]$. There are no limitations because of the advancements in communication media [4]. The internet helps transfer the information faster [6,7] and increases the connections between men or between things and men [4].

The main challenge in the development of Industry 4.0 is that technology will shift the work structure in daily life and resulted in diminishing many other jobs [4]. Besides changing the work system, the technology applied requires creative and innovative human capital [1]. Therefore, a new set of competencies develop that differs significantly from the current set of skills [8]. The limitless boundaries between humans, machines, and other resources positively affect numerous areas, including education [5]. Hence, changes made in teaching strategies and technology applied in the educational process will eventually require the teacher to develop a new set of competencies.

Due to technological advancement, the learning environment that enables students to contribute in this 4.0 era has led to a shift in the conventional learning paradigm towards technology-based learning $[2,5]$. This technology adaptation would impact almost all academic elements, such as program development, developing teacher knowledge and qualifications, and in the learning process [5]. It is essential, therefore, to emphasise teachers' competencies to facilitate the process of adaptation to 
technology and innovation in the educational process.

A teacher is vital to the education system [9-11]. Teachers' task is to prepare, advise, instruct, lead instruction, assess, and review student's achievement. As the world keeps changing and developing, there is a need to refine the quality of the human capital to compete on a global scale, especially in the industrial area [5]. Vocational education which is also known as technical and vocational education training (TVET) [12], emphasises education that adapts to demand-driven in the industry [3]. Thus, TVET teachers should master new competencies comprehensively to nurture graduate that meets the current industrial demand [8]. Teacher competencies are the teacher's ability to achieve learning goals in the learning process [1]. Teachers are responsible to transfer knowledge, attitude, and spiritual growth to balance academic maturity and cognitive attitudes, especially in current technology development [5]. Consequently, TVET teachers need to improve their competencies and the ability to adapt to new technologies and global challenges.

The vocational institution is aiming to produce skilled and competitive, industry-friendly graduates for the current industrial setting [3, 12, 13]. Grollmann [14] believed that becoming a vocational educator is challenging because of the broad spectrum of vocational education. Vocational teachers should extensively master their competencies to present vocational training that can facilitate future human capital that meets the necessity of this digital era [8]. Besides their pedagogical abilities, a skilled teacher requires other professional competencies to adapt accordingly in current technology [15]. Therefore, vocational teacher professional competencies need to be at par with the latest technological features. This study will identify and list the competencies required by TVET teachers to improve their performance in line with the development of the Industrial Revolution 4.0 technology.

\section{Methodology}

This study aims to identify the list of TVET Teacher professional competencies needed in the Industrial Revolution Era and to develop the TVET Teacher Professional Competencies framework in Industry 4.0 era. The research questions that guide this study are as follows:

1. What are the construct of TVET teacher professional competencies that aligned with the Industrial Revolution 4.0 era?

2. What are the sub-construct of TVET teacher professional competencies that aligned with the Industrial Revolution 4.0 era?

Previous studies on teacher competence analysed their data using a systematic literature review (SLR) method. There are four stages of the SLR method executed in this study, which are identification, screening, eligibility, and inclusion [16]. In the first stage, identification, a few keywords were used to identify relevant articles for this study. The main keywords chosen for inclusion in this study are "Teacher Competencies", "Industry 4.0", and "TVET". Other than that, the use of alternative terms and synonyms is also identified to accommodate variations in the spellings as shown in Table 1.

Table 1. Alternative keyword and synonym

\begin{tabular}{|l|l|}
\hline Main Keyword & Alternative term \\
\hline Teacher Competencies & $\begin{array}{l}\text { "Educator Competencies", "Teacher } \\
\text { skill," "Educator Skills", "Teacher } \\
\text { abilities", "Educator abilities." }\end{array}$ \\
\hline Industry 4.0 & $\begin{array}{l}\text { "Industrial Revolution 4.0", "Digital } \\
\text { Era","21st century" }\end{array}$ \\
\hline
\end{tabular}

The word AND was included in the keywords for a more extensive range of findings and expand the search into a specific study of teacher competencies and the operator OR to accommodate alternative spelling and synonyms $[17,18]$. For this purpose, open-access journals were used, and the search was conducted on Scopus online databases. Although the Industry 4.0 concept was introduced in Germany in 2011 [19], due to rapid technological changes, this study will only refer to the article from 2015 to 2020 . This effort effectively captured a sum of 208 journals and conferences related to the teacher competencies. In the screening phase to select the papers relevant for this study, the exclusion and inclusion criteria presented in Table 2 below were applied.

Table 2. Alternative keyword and synonym

\begin{tabular}{|l|l|}
\hline Exclusion/Inclusion & Criteria \\
\hline \multirow{5}{*}{ Exclusion } & Duplication (DP) \\
\cline { 2 - 2 } & Language compatibility (LC) \\
\cline { 2 - 2 } & No full-text (NF) \\
\cline { 2 - 2 } & Non-related (NR) \\
\cline { 2 - 2 } & Casually applied (CA) \\
\hline \multirow{3}{*}{ Inclusion } & Partially related (PR) \\
\cline { 2 - 2 } & Closely related (CR) \\
\hline
\end{tabular}

The first step in selecting the research papers was to remove identified 12 duplicate (DP) papers, leaving only 196 papers. The initial screening process also excluded all 12 papers that were not in English (LC) and 58 papers to which there was no full access (NF). This effort leaves only 126 relevant papers that were qualified for inclusion after the initial screening process. These papers were then examined further to check their eligibility for inclusion.

Since the final phase of this SLR method was to include the most relevant papers that contain teacher competencies which aligned with industrial revolution development, a thorough step was executed further on the remaining papers. The relevant papers were scrutinised further by filtering the titles and abstracts to narrow down and eliminate papers which were not related to Industry 
4.0 and teacher competencies (NR). Those papers that loosely used the terms Industry 4.0 and teacher competencies (CA1) as well as those which addressed Industry 4.0 but did not focus on teacher competencies (CA2) were eliminated at this stage, leading to the exclusion of another 117 papers.

As a result, nine papers were selected to represent teacher competencies in industrial revolution 4.0. The eligible nine papers were classified according to two inclusion criteria. Firstly, papers that focus on teacher competencies in industry 4.0 but not specifically on the TVET teacher profession (Primary School, Secondary School, Higher Institution) (PR). Secondly, papers that explicitly discusses Industry 4.0 skills required in TVET teacher profession. Following this, a thorough study of these documents was carried out in the next step. Figure 1 below presents the SLR stages applied in this study.

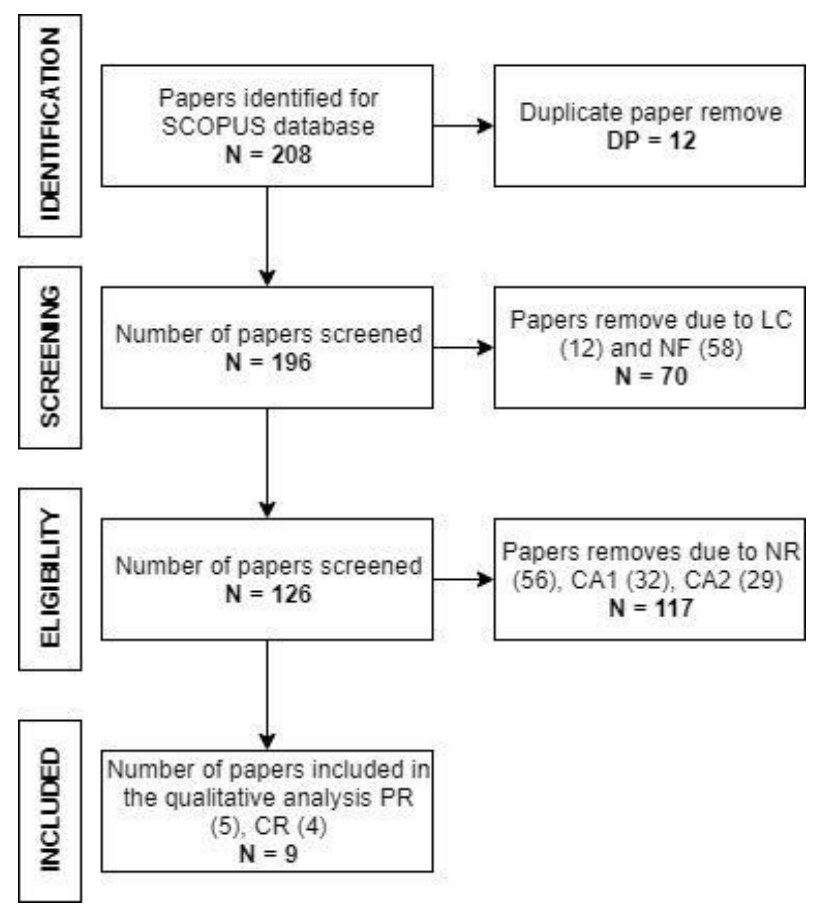

Figure 1. Systematic Literature Review Stages

\section{Findings}

Teacher competencies have been discussed in many previous studies. Therefore, the paper selection must strictly adhere to the teacher professional competencies that are needed to increase teacher performance in the industrial revolution 4.0 era. The document that only listed the main competencies but did not explain further about the element of the competencies discussed were considered ineligible for this analysis. As such, these documents were discarded.

The teacher competencies for Industry 4.0, presented in Table 3, were extracted from the research papers that fulfilled the eligibility criteria discussed in section 2 above.
All the teacher competencies necessary for Industry 4.0 were taken into consideration, thus providing a broad set of competencies needed by TVET teachers. As illustrated in Table 3, there are a few similar competency dimension related to knowledge, skills and attitude needed by the teacher in the Industry 4.0 era discussed in each paper analyse. Each competency indicated in relevant papers was coded and categorised into five main themes, which will become one construct. Each construct consists of codes that are related to each other, which will become the sub-construct of competencies.

Teacher professional competence is defined as the skills of a professional teacher capable of realising themselves in specific types of work, adapting to the changing need in their profession, and managing their professional mobility and self-regulation [23]. Five constructs which are needed by TVET Lectures in Industry 4.0 era emerged from the analysis conducted in this study. They are technical competencies, non-technical competencies, personal attributes, motive and self-construct, and mental and physical fitness.

Technical competencies listed in this study are explicitly related to TVET teacher roles in the instructional and learning process in industry 4.0 era. The sub-constructs for technical competencies are in the aspect of mastering the subject matter, instructional planning, instructional delivery, instructional evaluation, classroom management, motivating and facilitating student, student career development, and technology application.

The second construct is non-technical. Non-technical competencies related to other value and life skills needed by TVET teachers to support the acquisition of technical competencies in the digital era. The non-technical competencies listed in this research are creativity, critical thinking, analytical, collaboration, communication, ethical, innovative, leadership, lifelong learning, professional development, research, and social and cultural awareness.

The third construct is personal attributes. Personal attributes are the characteristics and personal qualities of a TVET teacher. The finding of this study listed approach, emotion control, flexibility, humanity, openness, risk-taking, role model and team player as personal attributes needed by TVET teacher in industry 4.0 era.

Motive is also considered as one of TVET teacher professional competencies in this study. Motives are the thoughts and desires that motivate one's behaviour to do something and be more successful - this construct listed meaningfulness of life and self-concept as the finding of this study. Final constructs are physical and mental fitness that refers to the ability of TVET a teacher to endure the toughness of vocational education process. Figure 2 summarises the related sub-constructs of competency that have been categorized into five main constructs based on SLR document analysis conducted in this study to represent the professional competency framework of TVET teachers in industry era 4.0. 
Table 3. Analysis of TVET Teacher Professional Competencies

\begin{tabular}{|c|c|c|c|c|}
\hline Author (s) & Study Domain & Methodology & Construct & Dimension \\
\hline \multirow{2}{*}{$\begin{array}{l}\text { Almerich et al., } \\
2016[20]\end{array}$} & \multirow{2}{*}{$\begin{array}{l}\text { Primary, } \\
\text { Secondary and } \\
\text { Higher Education } \\
\text { Teacher }\end{array}$} & \multirow{2}{*}{ Survey } & $\begin{array}{l}\text { Technological } \\
\text { Competence }\end{array}$ & $\begin{array}{l}\text { 1. Handling \& using a computer; 2. Basic computer application; 3. multimedia \& presentation; and 4. information \& } \\
\text { communication technology }\end{array}$ \\
\hline & & & $\begin{array}{l}\text { Pedagogic } \\
\text { competence }\end{array}$ & $\begin{array}{l}\text { 1. Planning Teaching; 2. Ethical \& Legal Problem; } 3 \text {. Designing \& enriching environment with ICT; and } 4 \text {. Innovation } \\
\& \text { communication }\end{array}$ \\
\hline \multirow{6}{*}{$\begin{array}{l}\text { Mohamed Ally, } \\
\text { 2019.[21] }\end{array}$} & \multirow{6}{*}{$\begin{array}{l}\text { Digital teacher of } \\
\text { the future }\end{array}$} & \multirow{6}{*}{$\begin{array}{lr}\text { conducted } & \text { focus } \\
\text { groups } & \text { and } \\
\text { interview } & \end{array}$} & $\begin{array}{l}\text { General } \\
\text { competencies }\end{array}$ & $\begin{array}{l}\text { 1. Be comfortable working in a virtual environment; } 2 \text {. Provide support ef for learners regardless of location and time; } \\
\text { 3. Work from anywhere and at any time; } 4 \text {. Teach students life skills; } 5 \text {. Keep up with emerging learning technologies to } \\
\text { use in education; } 6 \text {. Keep current content area to facilitate learning; } 7 \text {. Encourage students to be good citizens; } 8 \text {. Basic } \\
\text { knowledge of artificial intelligence; } 9 \text {. State of the art (current) knowledge in the subject area; } 10 \text {. Collaborate virtually } \\
\text { with other teachers to share information on learners' progress; } 11 \text {. Share effective learning practices with other teachers; } \\
\text { and } 12 \text {. Prepare learners to live in harmony with the environment }\end{array}$ \\
\hline & & & $\begin{array}{l}\text { Use digital } \\
\text { technology }\end{array}$ & $\begin{array}{l}\text { 1. Be digitally literate; } 2 \text {. Integrate technology in the curriculum seamlessly; } 3 \text {. Be comfortable when using technology; } \\
\text { 4. Use learning analytics to monitor individual learner progress; } 5 \text {. Use assistive technology to provide support to } \\
\text { learners with special needs; } 6 \text {. Integrate augmented reality, virtual reality, and mixed reality to give learners a real life } \\
\text { experience; } 7 \text {. Troubleshoot basic technology problems; } 8 \text {. Adapt to emerging technologies; } 9 \text {. Use multimedia } \\
\text { technologies to deliver learning materials in a variety of formats; } 10 \text {. Ability to independently learn how to use new } \\
\text { technology and software; } 11 \text {. Use technology to provide efficient support for learners; } 12 \text {. Have knowledge of the } \\
\text { culture and local practice to select the most appropriate technology; } 13 \text {. Explore emerging technologies for learning; } 14 \text {. } \\
\text { Use features of the technology to enrich the learning process; and } 15 \text {. Adapt the technology to the needs of the learner }\end{array}$ \\
\hline & & & $\begin{array}{l}\text { Develop digital } \\
\text { learning resources }\end{array}$ & $\begin{array}{l}\text { 1. Have knowledge of the content; } 2 \text {. Select the appropriate digital technology to match the content and the learning } \\
\text { outcome; } 3 \text {. Create high quality digital learning materials; } 4 \text {. Develop learning materials to meet specific learner's } \\
\text { needs; } 5 \text {. Develop learning materials with limited knowledge of the learner (language, culture, situation); } 6 \text {. Identify } \\
\text { quality and valid learning materials for learners to access; } 7 \text {. Use different strategies for different learning situations; } 8 \text {. } \\
\text { Use problem based learning to develop learners' high level knowledge and skills; and 9. Share learning resources with } \\
\text { other teachers. }\end{array}$ \\
\hline & & & $\begin{array}{l}\text { Re-mix digital } \\
\text { learning resources }\end{array}$ & $\begin{array}{l}\text { 1. Select appropriate digital learning resources to maximize learning; } 2 \text {. Access appropriate open education resources to } \\
\text { integrate into the curriculum; } 3 \text {. Modify the learning resources to align with the learning outcome; } 4 \text {. Re-mix open } \\
\text { education resources to meet the needs of individual learners; and } 5 \text {. Assess the quality of open education resources. }\end{array}$ \\
\hline & & & Communication & $\begin{array}{l}\text { 1. Communicate at the level of the learner; } 2 \text {. Use appropriate non-verbal communication when interacting with learners } \\
\text { using two-way video and text; } 3 \text {. Model good digital citizenship when using social media to communicate with learners } \\
\text { and peers; and } 4 \text {. Communicate in the language of the learner }\end{array}$ \\
\hline & & & Facilitate Learning & $\begin{array}{l}\text { 1. Personalise the learning for individual learners; } 2 \text {. Respond to learners' questions in a timely manner; } 3 \text {. Ability to } \\
\text { change strategies on the fly when supporting the learner to meet the learner needs; } 4 \text {. Respect different learner types and } \\
\text { adapt to the learner; } 5 \text {. Encourage creativity; } 6 \text {. Encourage innovation; } 7 \text {. Be a good listener; } 8 \text {. Provide appropriate } \\
\text { feedback; } 9 \text {. Show enthusiasm about the learning materials; } 10 \text {. Model working in the digital age; } 11 \text {. Motivate students } \\
\text { to learn; } 12 \text {. Encourage social interaction between learners; } 13 \text {. Ability to formulate good questions when interacting } \\
\text { with learners; } 14 \text {. Model good virtual behavior; } 15 \text {. Be approachable; } 16 \text {. Promote and model digital citizenship and } \\
\text { responsibility; } 17 \text {. Encourage authentic learning; } 18 \text {. Inspire learners; } 19 \text {. Create a comfortable learning atmosphere; } 20 \text {. } \\
\text { Provide feedback to individual learners to meet their individual needs; } 21 \text {. Interpret learner dashboard to monitor each } \\
\text { learner performance; } 22 \text {. Interpret learners' question; } 23 \text {. Solve learners' problems; } 24 \text {. Provide support to learners who } \\
\text { are on the go; } 25 \text {. Act as a coach for learners; } 26 \text {. Act as a mentor for learners; } 27 \text {. Support learners using digital } \\
\text { technology; } 28 \text {. Be an expert in the content to help learners who will be at different points in the learning process; and } \\
\text { 29. Encourage learners to think outside of the box. }\end{array}$ \\
\hline
\end{tabular}




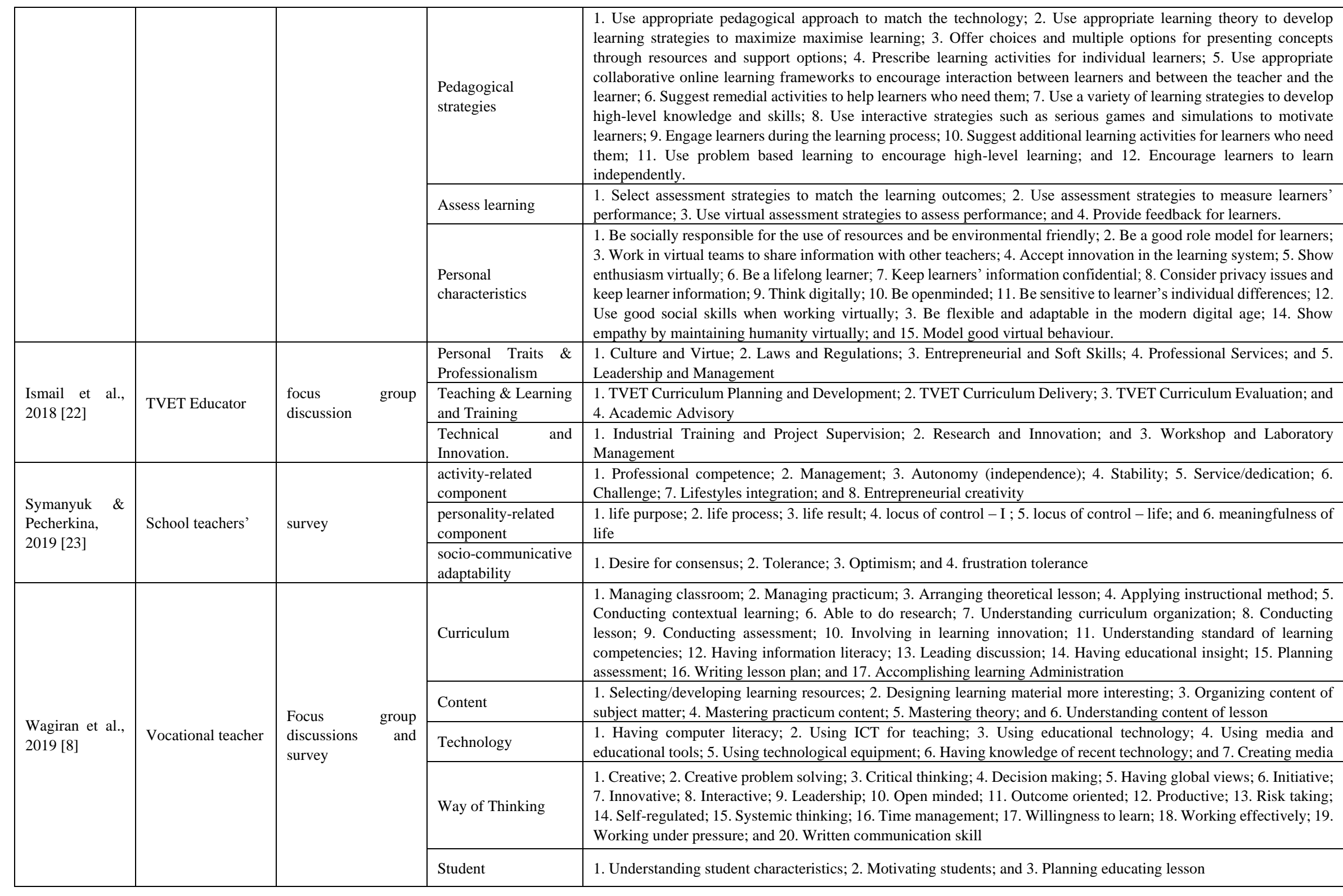




\begin{tabular}{|c|c|c|c|c|}
\hline & & & Living in the world & $\begin{array}{l}\text { 1. Able to manage conflict; } 2 \text {. Applying ethics } 3 \text {. Calm and confident; } 4 \text {. Compliance with rule; } 5 \text {. Discipline; } 6 . \text {. } \\
\text { Empathy; } 7 \text {. Encouraged to achieve; } 8 \text {. Exemplary; } 9 \text {. Flexible and adaptive; } 10 \text {. Friendly and sociable; } 11 \text {. Health and } \\
\text { stamina; } 12 \text {. Honest and trustable; } 13 \text {. Involving in school empowerment; } 14 \text {. Knowing school condition; } 15 \text {. Knowing } \\
\text { school environment; } 16 \text {. Mature; } 17 \text {. Neat performance; } 18 \text {. Orderline; } 19 \text {. Polite; } 20 \text {. Positive work attitude; } 21 . \\
\text { Prestige; } 22 \text {. Religious; 23. Respectful; } 24 \text {. Responsible; } 25 \text {. Self-concept; 26. Self-control; 27. Spirit at work; } 28 . \\
\text { Tolerance; and 29. Work ethic }\end{array}$ \\
\hline & & & Methods of working & $\begin{array}{l}\text { 1. Able to give advice; } 2 \text {. Able to share creative ideas; } 3 \text {. Able to speak foreign language; } 4 \text {. Collaborative with school } \\
\text { elements; } 5 \text {. Communication skills; } 6 \text {. Competitive and sportsmanlike; } 7 \text {. Cooperative; } 8 \text {. Implementing plans; } 9 \text {. } \\
\text { Listening skill; } 10 \text {. Negosiation; } 11 \text {. Organisation skill; } 12 \text {. Organising programs; } 13 \text {. Presentation skill; } 14 \text {. Report and } \\
\text { evaluate activities; } 15 \text {. Report writing; } 16 \text {. Supple and polite in communication; and } 17 \text {. Working durability }\end{array}$ \\
\hline & & & Tools for working & 1. Able to analyse information; 2 . Able to create timetable; 3 . Able to plan programs; 4 . Able to use IT \\
\hline \multirow{2}{*}{$\begin{array}{l}\text { Abdullah et al., } \\
2019[24]\end{array}$} & \multirow[b]{2}{*}{ TVET lecturer } & \multirow[b]{2}{*}{ Survey } & Professionalism & 1. Professional ethics; 2. Professional character; 3. Potential; and 4. Practice of professional learning community \\
\hline & & & Generic & $\begin{array}{l}\text { 1. Communicative skills; } 2 \text {. Collaborative skills; } 3 \text {. Problem-solving skills; 4. Decision-making skills; } 5 \text {. Interpersonal } \\
\text { skills; 6. Entrepreneurship skills; } 7 \text {. Management; and } 8 \text {. ICT }\end{array}$ \\
\hline \multirow{6}{*}{$\begin{array}{l}\text { Smolyaninova } \\
\& \\
\text { Bezyzvestnykh, } \\
2019[25]\end{array}$} & \multirow{6}{*}{ Trainee teachers } & \multirow{6}{*}{ Document Analysis } & $\begin{array}{l}\text { Motivational and } \\
\text { target-based }\end{array}$ & $\begin{array}{l}\text { 1. Understanding the importance of using ICT, including ePortfolio in professional activity; } 2 \text {. Motivation for using ICT } \\
\text { in professional activity(including ePortfolio); 3. Network etiquette (including information security), protection of } \\
\text { personal data in ePortfolios }\end{array}$ \\
\hline & & & $\begin{array}{l}\text { Cognitive } \\
\text { activity-based }\end{array}$ & $\begin{array}{l}\text { 1. Understanding the nature and content of information; } 2 \text {. Reviewing, searching and selecting data, information and } \\
\text { educational content to create and develop an ePortfolio; and } 3 \text {. Evaluation and management of data, information and } \\
\text { content by means of ePortfolio }\end{array}$ \\
\hline & & & Communicative & $\begin{array}{l}\text { 1. Interaction by means of ICT in information and educational environment (IEE); } 2 \text {. Exchange and mediation by means } \\
\text { of ICT in IEE; and 3. Collaboration using ICT, including ePortfolio, in IEE }\end{array}$ \\
\hline & & & $\begin{array}{l}\text { Tool-based and } \\
\text { activity-based }\end{array}$ & $\begin{array}{l}\text { 1. Development of educational content by means of ePortfolio; } 2 \text {. Development of an ePortfolio; and 3. Integration and } \\
\text { processing of educational (e-learning) content by means of ePortfolio }\end{array}$ \\
\hline & & & $\begin{array}{l}\text { Reflexive and } \\
\text { evaluative }\end{array}$ & $\begin{array}{l}\text { 1. Design and evaluation of individual progress, individual educational trajectory by means of ePortfolio; } 2 \text {. Assessing } \\
\text { adequate use of ICT; and 3. Assessing pedagogical support of students' reflection of the results of individual } \\
\text { educational trajectories being implemented, curricular, and projects by means of ePortfolio }\end{array}$ \\
\hline & & & $\begin{array}{l}\text { Personality-related } \\
\text { and creative }\end{array}$ & $\begin{array}{l}1 \text { Creative use of ICT in professional activity; } 2 \text {. Identifcation of individual needs; } 3 \text {.creative character of using ICT by } \\
\text { means of ePortfolio; and 4. Identifying ICT competency defciencies }\end{array}$ \\
\hline \multirow[b]{2}{*}{$\begin{array}{l}\text { Rofiq et al., } \\
2018[26]\end{array}$} & \multirow[b]{2}{*}{$\begin{array}{l}\text { Vocational teacher } \\
\text { candidates }\end{array}$} & \multirow[b]{2}{*}{ Survey } & Pedagogic & $\begin{array}{l}\text { 1. Able to prepare the learning tools; } 2 \text {. Mastery of the learning strategy; } 3 \text {. Able to educate; } 4 \text {. Mastery the information } \\
\text { technology to support the learning; } 5 \text {. Able to create a pleasant learning atmosphere; } 6 \text {. Able to make and use a learning } \\
\text { media; } 7 \text {. Have skill of class mastery; } 8 \text {. Have presentation skills; } 9 \text {. Emphasizes on student creativity; } 10 \text {. Can deliver } \\
\text { the knowledge to students; and } 11 \text {. Able to apply bilingual learning, mastering the foreign languages(especially } \\
\text { English) }\end{array}$ \\
\hline & & & Field of the Expertise & $\begin{array}{l}\text { 1. Mastery of the basic theory of engineering; } 2 \text {. Mastery of both theoretical and practical material in mechanical } \\
\text { engineering; } 3 \text {. Mastery of the knowledge and skills on productive subjects to the complex level; } 4 \text {. Have the field of } \\
\text { expertise, proven by a certificate of competence; } 5 \text {. Having competency in the field of expertise according to industry } \\
\text { standards to prepare prospective workers; } 6 \text {. Mastery a particular field in depth (specialist); and } 7 \text {. Have experience in } \\
\text { the field (industry) as supporting competence }\end{array}$ \\
\hline
\end{tabular}




\begin{tabular}{|c|c|c|c|c|}
\hline & & & Managerial & Have a managerial competency \\
\hline & & & Personality & $\begin{array}{l}\text { 1. Have a strong personality; } 2 \text {. Have a tough mental; } 3 \text {. Self-confident; } 4 \text {. Noble character; } 5 \text {. Have an awareness as } \\
\text { educator and } 6 \text {. Always perform self-development }\end{array}$ \\
\hline & & & Social & $\begin{array}{l}\text { 1. Able to interact with the entire school's communities; 2. Adaptive to technological developments; and 3. Able to } \\
\text { provide a career understanding to students }\end{array}$ \\
\hline \multirow{3}{*}{$\begin{array}{l}\text { Thongkam et } \\
\text { al., } 2018[27]\end{array}$} & \multirow{3}{*}{$\begin{array}{l}\text { Vocational college } \\
\text { instructor }\end{array}$} & \multirow{3}{*}{ Survey } & Knowledge & $\begin{array}{l}\text { 1. Classroom management; } 2 \text {. Measurement and evaluation; } 3 \text {. Research on development technology; } 4 \text {. curriculum and } \\
\text { learning management; } 5 \text {. being a professional teacher; } 6 \text {. psychology for teachers; 7. self-improvement; } 8 \text {. } \\
\text { Communication; and } 9 \text {. professional knowledge }\end{array}$ \\
\hline & & & Skill & $\begin{array}{l}\text { 1. Measurement and evaluation; 2. Classroom management skill 3. curriculum and learning management skill; } 4 . \\
\text { Psychology for teacher skill; 5. Communication; 6. Research on development skill; 7. Technology skill and } 8 \text {. } \\
\text { Self-improvement skill }\end{array}$ \\
\hline & & & Attribute & 1. Attitude towards the teaching profession; 2. Personality; and 3. Ethics of the teaching profession \\
\hline
\end{tabular}




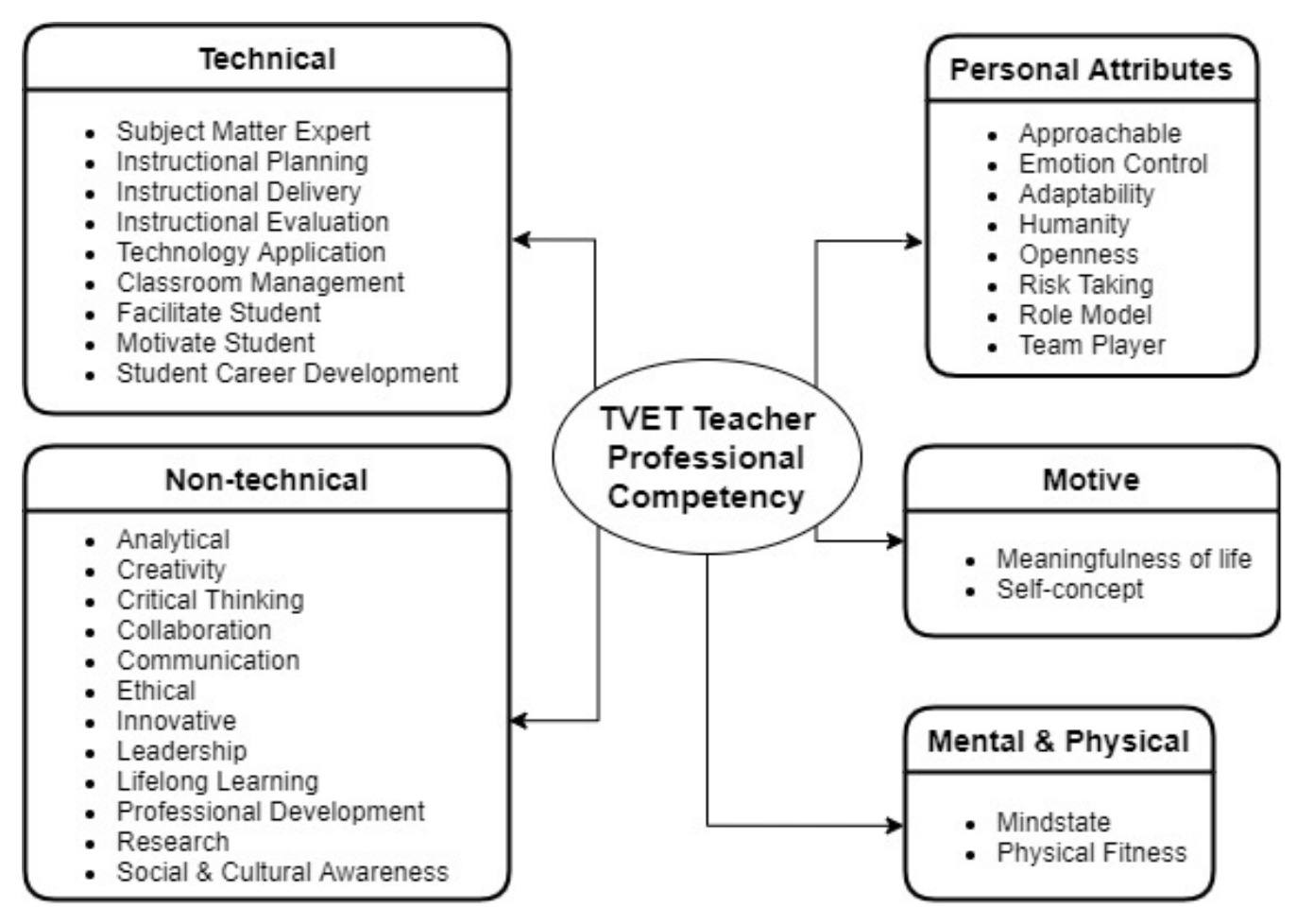

Figure 2. Proposed TVET Teacher Professional Competency Framework in Industry 4.0 Era

\section{Discussion}

\subsection{Technical Competencies}

Teachers' roles are to prepare, advise, instruct, lead instruction, assess, and review students' achievement. TVET teacher involves theoretical and practical learning sessions in diverse ways. Hence, the emphasis in technical competencies is vital for TVET teacher professional development in the Industrial Era [22]. This technical competency includes instructional planning, instructional delivery, instructional evaluation, classroom management, motivating and facilitating student, student career development, technology application and mastering subject matter that is important to TVET education in industry 4.0 era.

During the instructional planning process, TVET teacher should able to evaluate the technological resources available [20] before selecting an appropriate learning tool and resources $[8,26]$. They need to plan, design and organize their curriculum material $[8,20,22]$ and write lesson plans which are [8] suitable to the technological resources available to maximize the learning [21]. However, teachers today face students who use smart devices since their early age [21]. Hence, it is essential that the TVET teacher efficiently plan and prepare their teaching activities [28]. TVET teacher also needs to personalise the learning for individual learner [21] and integrate the educational content digitally by using e-learning [25] to cater to the learning need of this generation.
In industry 4.0 era, TVET teacher needs to effectively execute their instructional plan in delivering the knowledge and life skill to educate the student $[8,21-23,26]$. On top of that, TVET teacher needs presentation skill to engage with the student during the learning process $[8,20,26]$. Also, TVET teacher needs to use appropriate pedagogical approach to match the technology available $[21,26]$ and apply different learning strategies for different learning situation $[8,21,26]$ to maximise the learning and develop high-level knowledge and skill in the industry 4.0 era

Other than that, TVET teacher needs to be able to plan, conduct $[8,27]$ and select assessment strategies and measure the student performance to match the learning outcome [21, 22]. In this digital era, TVET teacher should be able to do assessment virtually [21], make use of technology such as e-portfolio as evaluation instrument $[20,25]$.

TVET teacher should be able to manage and organize their classroom and workshop to have a conducive learning environment [8, 22-27]. They also need to have interpersonal and time management skill [8] to organise curriculum and learning activities for effective teaching and learning process $[8,27]$. TVET teacher also needs to understand their students' characteristics [8] to give appropriate feedback to meet the students' needs and be able to utilise technology for additional learning activities [21]. In line with the current technological developments, teachers needs to encourage students to be creative and innovative with the learning resources available and also to motivate students to learn independently $[8,21,26]$. The way TVET teachers manage their classes, facilitate and 
motivate their students determined the success of student learning [3].

Other than that, TVET teachers need to able to supervise industrial training and project supervision [22]. They also need to provide career understanding and advice for students $[22,26]$. Vocational education aims to produce skilled and competitive worker for an industrial setting [3, $12,13]$. Thus, TVET teachers are expected to equip their students with the relevant industrial knowledge to facilitate the transition from school to work $[8,14,15]$.

Besides that, TVET teachers should demonstrate mastery of skills and knowledge in their subject matter $[8,21,25,26]$. The rapid development of technology used in the industry has required TVET teachers to understand and update the curriculum and syllabuses used in their respective institutions to meet industrial needs $[8,25]$. TVET teachers need to frequently update and master their theoretical knowledge, practical skills and have industrial experiences to support and facilitate students at different points in the learning process $[8,21,26]$.

Finally, technology application is also considered as one of the sub-construct in technical competencies discussed in this study. In the rapid advancement of this digital age, teachers' ability to leverage the use of new technologies in the teaching process is highly significant $[8,20,21,24,27]$. TVET teachers are required to be digitally literate $[21,20,8]$ and able to use educational technology tools and software applications that help them to plan, deliver and evaluate their instructional process effectively $[8,20]$.

\subsection{Non-Technical Competencies}

Non-technical competencies is also referred to generic or 'soft' skills [24]. Competent professional TVET teachers must balance both their technical competencies and non-technical competencies to remain relevant [8]. To achieve this, TVET teachers need to develop their professionalism with strong non-technical skills and essential skills [22]. Due to the rapid change in technological advancement that demands relatively new sets of skills, lifelong learning has become the essential skill for TVET teacher career development [8]. TVET teachers need to keep up and be willing to learn and exploring emerging learning technologies used in education independently $[8,21]$.

Because of that, TVET teachers need to have the skills to conduct research [8]. TVET teachers should be able to review, searching and selecting data, information and educational content to develop learning material and resources $[8,22,25,27]$. This research skill is needed for teacher skill development and innovation of learning material to enhance the learning process [22,27].

Besides that, the shift in the education paradigm in the digital era also requires TVET teachers to incorporate technology creativity $[8,20,21,25,26]$ innovation $[8,20,21]$ and critical thinking $[8,21,24]$ in the learning process and teaching strategies. The teacher needs to creatively design learning material by utilizing technology to meet student-specific need $[8,20,21,25]$ and conducive learning environment [26]. TVET teacher needs to be innovative in making new learning material [26], actively involved in learning innovation by integrating technology in curriculum and use technology feature to enrich the learning process $[8,20,21]$. Critical thinking skill will help TVET teacher with problem-solving $[8,24]$ and modify the learning resources to align with the learning outcome [21]. Besides critical thinking skill, TVET teacher also need analytical skill to analyses and searching information $[8,20]$, identify quality and valid learning material [21], identify student need, and monitor student progress [25]

In addition, collaboration $[8,20,21,24,25]$ and communication skill $[8,20,21,24-27]$ are also needed by TVET teacher in industry 4.0 era. TVET teacher needs to collaborate virtually with other educational community by sharing learning material, effective learning strategies and learner progress information [8,20,21,25]. The collaboration will be more successful with effective communication [20]. TVET teacher needs to have written, listening [8,21] and communicative skill [8,21,24,27]. They also need the ability to communicate in a different language $[8,26]$ and are able to utilize technology such as the internet to communicate effectively $[20,21,25]$.

Next, TVET teacher needs to enhance their professional development $[8,23,27]$. In this advance era, TVET teacher should have the ability to use technology such as e-portfolio to perform self-development and self-improvement [25,26,27]. They need to have professional knowledge and attitude toward the teaching profession [22,23,27] and also involve in school empowerment [8]. They also need to have educational insight and awareness of being an educator $[8,26]$. However, professional teaching profession should also prioritise ethics in their careers $[8,24,27]$. TVET teacher should apply professional work ethic $[8,24,27]$ especially to keep learners' information confidential when using the technological resources $[21,25]$.

Further, TVET teacher also needs leadership skill $[8,22,24]$ Leadership skill includes the ability to lead the discussion [8], making the decision, manage conflict $[8,24]$ and negotiate [8]. Lastly, TVET teacher needs to have social and environmental awareness of understanding the school condition and environment [8]. They need to abide by the rules of both local schools and government and respect the culture of the local community $[8,22]$. The teacher also needs to prepare the student to live in harmony with the environment and be able to select the most appropriate technology that respects the culture and local practice [21].

\subsection{Personal Attributes}

TVET Teacher should be professional, have a pleasant 
personality to represent in his/her daily behaviour and possess high competence [30]. The gentle character of the teacher to enhance human relationships will become a demand in this digital era [1]. TVET teacher should be friendly [8] and easy to approach [21]. They also need to be calm and confident $[8,23]$, mature, sensitive to students' differences and show enthusiasm during the teaching and learning process [21].

Next is teacher adaptability. Due to the rapid advancement of technology, teachers should be able to work comfortably and be adaptive to technological advancement. $[21,26]$. TVET teachers should be able to adapt to emerging technology, change strategies accordingly to support student need [21]. They also need to be flexible and able to work anywhere to provide support for students $[8,21]$. TVET teachers also need to become a team player $[8,23,24]$. They need to have initiative, discipline, positive work attitude, be cooperative, interactive, productive, responsible, outcome-oriented, efficient [8], independent, dedicated [23] and professional [24].

Even though this digital era is focusing on the technology, TVET teachers should have the values of humanity in themselves $[8,21,23]$. TVET teachers should have honesty, politeness, religiousness, respect toward others, [8] empathy $[8,21]$ and tolerance $[8,23]$. In addition, TVET teacher should be open-minded and ready to face challenges and risk $[8,21]$. Consequently, teachers are required to prepare human capital without losing humanity, personality, and culture value [4]. Thus, teachers should have excellent personal characteristics to serve as a role model for students as well as provide quality education and support for students $[8,21,26]$.

\subsection{Motive}

Symanyuk \& Pecherkina [23] stated that "desire to build one's own life" as one aspect requires for the professional development of a teacher. Self-concept, self-development, self-control are also considered as the component of teacher competencies in the industrial era [8]. With more teaching experience, teachers become more detailed and their self-perception as a successful person was formed; the emotional richness of life increases and the desire for professional self-development and independence become more important [23]. TVET teachers require for self-concept, including self-confident, self-improvement and personality, to motivate themselves to develop and be more successful $[26,27]$. Hence, motive is included as a construct in this study.

\subsection{Mental \& Physical State}

Physical \& mental fitness is necessary because TVET education does not only involve theoretical learning but require mental and physical endurance while doing practical training $[22,27]$. Teachers should have a mental toughness to work under pressure[8,26] high spirit [8] optimism and stability [23]. TVET teachers also need to maintain their health and stamina and have working durability [8] as part of their competencies.

\section{Conclusions}

The SLR review answered both research questions in this study, which is to identify suitable construct and sub-construct of professional competencies needed by TVET teachers in Industry 4.0 era. The study pointed out that non-technical competency is as important as technical competence and reinforces with teacher personal attributes, their motive, and physical state in the TVET teacher profession in the Industry 4.0 era. In general, advanced technologies created are not to replace humans for improving productivity; instead, there must be close human-technology collaboration. Technical and academic institutions should create opportunities for technology adaptability, lifelong learning, and a future set of competencies to meet the challenge of the rapid change in professional competencies requirements for TVET teachers in Industry 4.0.

\section{Acknowledgements}

This research was funded by University Teknologi Malaysia Fundamental Research Grant Scheme (UTMFR), Universiti Teknologi Malaysia under research vote $20 \mathrm{H} 77$. Special thanks go to the Research Management Centre of Universiti Teknologi Malaysia for managing the activities of this research.

\section{REFERENCES}

[1] Ningsih, T. (2019). Smart Teachers in Developing Students' Character in 4.0 Industrial Revolution Era. Proceeding of 3rd International Conference on Empowering Moslem Society in the 4.0 Industry Era, 3, 58-68.

[2] Hong, S. K., \& Yoon, S. C. (2018). A Study on the Development of Teacher Competency Standards in Digital Textbook Environment. 9th International Conference on Information and Communication Technology Convergence: ICT Convergence Powered by Smart Intelligence, ICTC 2018, 291-296.

[3] Sunarto, \& Supriadi, D. (2018). The Professionalism of Vocational Teachers in Central Java and Yogyakarta. Innovation Issues and Challenges in Education for Education Sustainability, (August), 11-27.

[4] Indrawan, P. A., \& E.Lay, A. (2019). Guidance and Counseling Teachers' Competency Perspective in the Era of Industrial Revolution 4.0. International Journal of 
Innovation, Creativity and Change., 5(3), 147-161.

[5] Lase, D. (2019). Education and Industrial Revolution 4.0, 10(1), 48-62.

[6] Riyanto. (2011). Teknologi Informasi Pendidikan Membahas Materi Dasar Teknologi informasi yang wajib dikuasai pemula IT. Yogyakarta: Gava Media.

[7] Nanci Riastini, P., Widowati, A., Ratnasari, Y., \& Surya Darma, I. (2019). Enganging Balinese Culture and Technology in Digital Era: A Review to Foster Primary Teachers' Competencies. Advances in Social Science, Education and Humanities Research (ASSEHR), 330(ICERI 2018), 244-248.

[8] Wagiran, Pardjono, Suyanto, W., Sofyan, H., Soenarto, S., \& Yudantoko, A. (2019). Competencies of future vocational teachers: Perspective of in-service teachers and educational experts. Cakrawala Pendidikan, 38(2), 388-400.

[9] Johnston, J., Loyalka, P., Chu, J., Song, Y., Yi, H., \& Huang, $X$. (2016). The impact of vocational teachers on student learning in developing countries. Comparative Education Review, 60(1), 131-150.

[10] Köpsén, S. (2014). How vocational teachers describe their vocational teacher identity. Journal of Vocational Education and Training, 66(2), 194-211.

[11] Kukla-Acevedo, S. (2009). Do teacher characteristics matter? New results on the effects of teacher preparation on student achievement. Economics of Education Review, 28(1), 4957.

[12] Sudira, P. (2016). TVET Abad XXI: Filosof, teori, konsep, dan strategi pembelajaran vokasional [TVET 21 Century: Philosophy, theory, concept, and vocational learning strategy]. Yogyakarta: UNY Press.

[13] Billett, S. (2011). Vocational education: purposes, traditions and prospects. New York, NY: Springer

[14] Grollmann, P. (2008). The quality of vocational teachers: teacher education, institutional roles and professional reality. European Educational Research Journal, 7(4), 535547.

[15] Flynn, M. C., Lissy, R., Alicea, S., Tazartes, L., \& McKay, M. M. (2016). Professional development for teachers plus coaching related to school-wide suspensions for a large urban school system. Children and Youth Services Review, 62(March), 29-39.

[16] Menggist, W., Soromessa, T.\& Feyisa, G. L. (2019). Method for Conducting Systematic Literature Review and Meta-Analysis for Environmental Science Research. MethodsX. 100777.

[17] Aliyu, M.B. (2017) Efficiency of Boolean search strings for Information retrieval. American Journal of Engineering Research, 6(11): pp. 216-222.

[18] Kitchenham, B. (2004) Procedures for performing systematic reviews. Technical Report, Keele University, Staffs, pp. 1-26.

[19] Prifti, L., Knigge, M., Kienegger, H., \& Krcmar, H. (2017). A Competency Model for "Industrie 4.0" Employees. 13th International Conference on Wirtschaftsinformatik, 46-60.
[20] Almerich, G., Orellana, N., Suárez-Rodríguez, J., \& Díaz-García, I. (2016). Teachers' information and communication technology competences: A structural approach. Computers and Education, 100, 110-125.

[21] Ally, M. (2019). Competency profile of the digital and online teacher in future education. International Review of Research in Open and Distance Learning, 20(2), 302-318.

[22] Ismail, A., Hassan, R., Abubakar, A., Hussin, H., Mat Hanafiah, M. A., \& Asary, L. H. (2018). The development of TVET educator competencies for quality Educator. Journal of Technical Education and Training, 10(2), 38-48.

[23] Symanyuk, E. E., \& Pecherkina, A. A. (2016). A study on the components of teachers' professional competence. New Educational Review, 44(2), 198-210.

[24] Abdullah, Z., Hoque, K. E., Ramlan, N. H., \& Shafee, S. (2019). Designing the Structural Model of TVET Lecturers' Professionalism and Generic Skills Based on an Empirical Study in Malaysia. SAGE Open, 9(3), 1-18.

[25] Smolyaninova, O. G., \& Bezyzvestnykh, E. A. (2019). Professional training of teacher 4.0: Developing digital competency by means of ePortfolio. Journal of Siberian Federal University - Humanities and Social Sciences, 12(9), 1714-1732.

[26] Rofiq, Z., Surono, S., Bruri Triyono, M., \& Setiyo Hari Purwoko, B. (2019). Developing the Standard Competencies for Vocational Teacher Candidates of Mechanical Engineering. Journal of Physics: Conference Series, 1273(1), 1-10.

[27] Thongkam, K., Suwanjan, P., \& Pupat, P. (2019). Thai vocational college instructor teaching competency: A second order confirmatory factor analysis. Asia-Pacific Social Science Review, 19(1), 224-232.

[28] Zulkifli, R. M., Hussain, M. A. M., Hanapi, Z., Suhairom, N., \& Wahid, N. H. A. (2018). Industry-specific knowledge that vocational teachers should know and be able to do to prepare a job-ready workforce. Journal of Engineering Science and Technology, 13(2018), 14-22.

[29] Martínez, M. F. C., Mendoza Velazco, D. J., Cejas, M. N., Villacis, J. L. R., \& Freire, Y. M. O. (2019). A Performance-Centred Competency-Based Approach to Quality University Teaching. Integration of Education, 23(3), 350-365.

[30] Rozdi, Z. M., Ahmad, C. N. C., \& Mohamed, Z. (2016). Competency Model of Science Teacher in 21st Century. International Journal of Academic Research in Business and Social Sciences, 6(12), 2012-2017. R. F. Voss, J. Clarke. Algorithmic Musical Composition, Silver Burdett Press, London, 1986. 